November -2009

\title{
Open Educational Resources: New Possibilities for Change and Sustainability ${ }^{1}$
}

\author{
Norm Friesen \\ Thomson Rivers University, Canada
}

\begin{abstract}
In an attempt to understand the potential of OER for change and sustainability, this paper presents the results of an informal survey of active and inactive collections of online educational resources, emphasizing data related to collection longevity and the project attributes associated with it. Through an analysis of the results of this survey, in combination with other surveys of OER stakeholders and projects, the paper comes to an initial conclusion: Despite differences in priorities and emphasis, OER initiatives are in danger of running aground of the same sustainability challenges that have claimed numerous learning object collection or repository projects in the past. OER projects suffer from the same incompatibilities with existing institutional cultures and priorities that have dogged learning object initiatives, and they face the concomitant challenge of gaining access to the operational funding support that experience shows is necessary for their survival. However, through a review of one of the most successful of OER projects to date, the MIT Open Courseware Initiative, the paper ends by augmenting this significant caveat with a second, more hopeful conclusion: OER projects, unlike learning object initiatives, can accrue tangible benefits to educational institutions, such as student recruitment and marketing. Highlighting these benefits, it is argued, provides an opportunity to link OER initiatives to core institutional priorities. In addition to providing a possible route to financial sustainability, this characteristic of OER may help to foster the significant changes in practice and culture long sought by promoters of both learning objects and OERs.
\end{abstract}

Keywords: E-learning; open courseware; project sustainability; learning objects

\section{Background and Terminology}

The term open educational resources was first adopted at the 2002 UNESCO Forum on the Impact of Open Courseware for Higher Education in Developing Countries, sponsored by The William and Flora Hewlett Foundation. The term was defined as "the open provision of educational resources, enabled by information and communication technologies, for consultation, use and adaptation by a community of users for noncommercial purposes" (UNESCO, 2002, p.

\footnotetext{
${ }^{1}$ This paper was written with the support of the BC Centre for Open Learning.
} 
24). This definition and its emphasis on open availability and noncommercial use remains central in the way the term is used today, and the implied understanding that open courseware represents a kind of OER is one shared by this paper, and by other texts like it. The notion of openness, for its part, has been given legal force and definition through the set of copyright licenses released by Creative Commons, also in 2002. In their final declaration, the forum participants expressed "their wish to develop together a universal educational resource available for the whole of humanity to be referred to henceforth as Open Educational Resources" (p. 6). They contextualized this ambitious aspiration by comparing their vision to UNESCO's existing program for the identification and preservation of "cultural and natural heritage around the world considered to be of outstanding value to humanity" (UNESCO 2009): "Following the example of the World Heritage of Humanity, preserved by UNESCO, [we] hope that this open resource for the future mobilizes the whole of the worldwide community of educators" (UNESCO, 2002, p. 28).

These far-reaching humanitarian goals and prospects are still very much relevant to the use of the term open educational resources (OERs) and to terms such as open courseware (OCW) and open education generally. But for the comparison with UNESCO heritage sites to hold, issues of preservation and sustainability must be taken very seriously. There is little use in establishing a "universal educational resource" - however effective for human and educational development it may be - if it is neglected or goes offline after a few years. Finally, it is also important to note that the original organizations sponsoring this first meeting, UNESCO and the Hewlett Foundation, remain important in their support of ongoing OER and OCW efforts.

An obvious question at this point concerns the relationship of OERs to learning objects. Although a consensual definition of the term learning object has proven notoriously elusive (e.g., Wiley, 2000), a look at even a few of the many divergent definitions is telling. For example, the learning object has been defined as "a modular building block for e-learning content" (Allan, 2008), as an instructional element "grounded in the object-orientated paradigm" (Wiley, 2000, p. 2), and as a "digital self-contained and reusable entity" (Chiappe, Segovia, \& Rincon, 2007, p. 675). What is significant in each definition is precisely what is included and excluded: Each definition highlights (either directly or indirectly) modularity as a technological and design attribute for the object and its content, emphasizing the "self-contained," "building block" or "object-oriented" nature of the technology. This corresponds to a broader emphasis on technological solutions and standards that is evident in many learning object projects and publications. Mention of technical standards and of modular design, on the other hand, is conspicuously absent in discussion of OERs. ${ }^{2}$ A second general difference separating learning objects from their open educational counterparts is indicated by the absence of any explicit reference to the openness or the open and noncommercial character of the resource. Over the course of the 10 or more years that the term

\footnotetext{
${ }^{2}$ Significant reservations about the emphasis on the technological and technical standards of learning objects have been expressed in recent reports on OERs. For example, the OLCOS Roadmap 2012 associates the technically demanding Learning Object Metadata standard (containing 76 data elements) with learning objects but identifies RSS feeds and social bookmarking (utilizing folksonomies and 12 or fewer data elements) with OERs (Geser, 2007, p. 47).
} 
has been in use, learning objects have been associated with visions of "virtual market economies," "learning object economies," "digital rights protection management" technologies, and a variety of explicitly commercial models for project sustainability (Carey, 2003; Johnson, 2003; Downes et al., 2004).

\section{Collections of Online Materials}

Although OERs, learning objects, and other ways of defining educational content may be readily distinguished in theoretical and definitional terms, they are not so easily discriminated in practice. This is especially clear when the characteristics of repositories, databases, or collections of online educational resources are reviewed. Some of the longest-lived and thus most "successful" collections of resources have eschewed reference to learning objects, OERs, and other related nomenclature in facilitating and promoting the use of online educational resources. This suggests that some of the best examples available in practice are based on approaches not reducible to those of either of the OER or the learning object terms or categories. One could say that they have developed a vocabulary and self-understanding inductively from actual practices, rather than deriving them inductively from first principles. This includes the Multimedia Educational Resource for Learning and Online Teaching (MERLOT), which went online in 1997 and includes links to contents that are available both for free and for a fee. This also includes the collection of free online courses or course materials of the Massachusetts Institute of Technology (MIT). Announced with great fanfare in 2001, this project recently met its original ambitious goal of placing all of MIT's course content online by 2007. Additionally, this project effectively pioneered the notion of providing free access to course materials, and it also popularized the term open courseware. Correspondingly, it is one of the original inspirations for the "OER movement" (UNESCO, 2002, pp. 1-2), and it is significant for being one of the few early, high-profile online initiatives announced by a campus-based institution to survive to the present day. ${ }^{3}$ At the same time, this project is also conspicuous in its emphasis on MITs own institutional products or courses, rather than on collecting smaller units of content from a range of sources. As such, it offers a model that is both robust and distinct from efforts that make available smaller components or units of online courseware.

Still, the number of online collections of educational resources that are active at the time of writing is considerable, large enough, in fact, to make an exhaustive listing impossible or at least unwieldy. Instead, the collections listed in the table below are intended to be representative of the wide range of collection emphases, policies, and histories. (A similar, selective listing is provided by Yuan, MacNeill, \& Kraan, 2008.) The collections listed in Table 1 reflect the multiplicity of emphases and approaches in practice that confound neat attempts at compartmentalization. The data on the approximate number of resources in each collection, the indication of the subjects and educational domains addressed, and the type of copyright licensing implemented (if any) vary widely. A special effort was made to determine the source of funding for each collection or project as well as its start date, which is in most cases the year the collection first appeared online.

\footnotetext{
${ }^{3}$ Examples of conspicuous failures abound and include Cardean University, NYUonline, UNext, UK e-U, and Fathom (Columbia University).
} 
To help support some of the points made below, the collections listed have been grouped by the level of inclusiveness of the subject-matter and resource types: Collections inclusive of all subjects and all levels of education are listed first; those focusing on specific types of resources (video clips, entire courses, or particular kinds of course units) follow; and finally, collections providing resources specific to one subject or a small collection of subjects are listed.

Table 1

Selected Educational Resources Collections Currently in Operation (January 2009)

\begin{tabular}{|c|c|c|c|c|c|}
\hline Name/address & $\begin{array}{l}\text { Primary } \\
\text { sponsorship }\end{array}$ & $\begin{array}{l}\text { Subject/level } \\
\text { emphasis }\end{array}$ & $\begin{array}{l}\text { Items, } \\
\text { start } \\
\text { date }\end{array}$ & Types of content & Copyright \\
\hline \multicolumn{6}{|c|}{ A L L S U B J E C T S A N D R E S O U R C E T Y P E S } \\
\hline $\begin{array}{l}\text { Connexions } \\
\text { http://cnx.org/ }\end{array}$ & $\begin{array}{l}\text { Hewlett, Rice } \\
\text { University }\end{array}$ & $\begin{array}{l}\text { All subjects, } \\
\text { postsecondary }\end{array}$ & $\begin{array}{l}7000+ \\
(1999)\end{array}$ & $\begin{array}{l}\text { Courses, books, } \\
\text { reports, etc.; } \\
\text { includes own } \\
\text { content } \\
\text { authoring } \\
\text { system }\end{array}$ & $\begin{array}{l}\text { Creative } \\
\text { Commons }\end{array}$ \\
\hline $\begin{array}{l}\text { Curriki } \\
\text { http://www.curriki.o } \\
\text { rg/ }\end{array}$ & $\begin{array}{l}\text { Non profit; } \\
\text { unknown }\end{array}$ & $\begin{array}{l}\text { All subjects, all } \\
\text { levels }\end{array}$ & $\begin{array}{l}15,000+ \\
(2004)\end{array}$ & $\begin{array}{l}\text { All types, wiki- } \\
\text { integrated }\end{array}$ & $\begin{array}{l}\text { Creative } \\
\text { Commons }\end{array}$ \\
\hline $\begin{array}{l}\text { GEM Gateway to } \\
\text { Educational } \\
\text { Materials } \\
\text { http://thegateway.or } \\
\text { g/ }\end{array}$ & $\begin{array}{l}\text { National } \\
\text { Education } \\
\text { Association }\end{array}$ & $\begin{array}{l}\text { All subjects, all } \\
\text { levels }\end{array}$ & $\begin{array}{l}50,000+ \\
(2001 ?)\end{array}$ & All types & various \\
\hline $\begin{array}{l}\text { Intute } \\
\text { http://www.intute.ac. } \\
\text { uk/ }\end{array}$ & $\begin{array}{ll}\text { UK Joint Info. } \\
\text { Systems } \\
\text { Committee } \\
\text { (JISC) } \\
\end{array}$ & $\begin{array}{l}\text { All subjects, } \\
\text { postsecondary }\end{array}$ & $\begin{array}{l}100,000 \\
+(2007)\end{array}$ & All types & various \\
\hline $\begin{array}{l}\text { MERLOT } \\
\text { http://www.merlot.or } \\
\text { g/merlot/index.htm }\end{array}$ & $\begin{array}{l}\text { Membership fees; } \\
\text { gov’t } \\
\text { commercial }\end{array}$ & $\begin{array}{l}\text { All subjects, } \\
\text { postsecondary }\end{array}$ & $\begin{array}{l}20,000+ \\
(1999)\end{array}$ & All types & $\begin{array}{l}\text { Creative } \\
\text { Commons }\end{array}$ \\
\hline $\begin{array}{l}\text { OER Commons } \\
\text { http://www.oercom } \\
\text { mons.org }\end{array}$ & $\begin{array}{l}\text { Hewlett } \\
\text { Foundation }\end{array}$ & $\begin{array}{l}\text { All subjects, all } \\
\text { levels }\end{array}$ & $\begin{array}{l}20,000+ \\
(2007 ?)\end{array}$ & $\begin{array}{l}\text { All types, } \\
\text { including OCW, } \\
\text { modules, etc. }\end{array}$ & $\begin{array}{l}\text { Creative } \\
\text { Commons }\end{array}$ \\
\hline \multicolumn{6}{|c|}{$\begin{array}{lll}\text { S P E C I F I C R E S O U R C E T Y P E S }\end{array}$} \\
\hline http://edutube.org/ & Unknown & $\begin{array}{l}\text { All subjects; all } \\
\text { education levels }\end{array}$ & $\begin{array}{l}1000+ \\
(2007 ?)\end{array}$ & $\begin{array}{l}\text { Video clips } \\
\text { from YouTube }\end{array}$ & No info \\
\hline $\begin{array}{ll}\text { MIT } & \text { Open } \\
\text { Courseware } & \end{array}$ & $\begin{array}{l}\text { Hewlett } \\
\text { Foundation, }\end{array}$ & $\begin{array}{l}\text { All subjects, } \\
\text { postsecondary }\end{array}$ & $\begin{array}{l}2000+ \\
(2001)\end{array}$ & $\begin{array}{l}\text { Courses, course } \\
\text { components }\end{array}$ & $\begin{array}{l}\text { Creative } \\
\text { Commons }\end{array}$ \\
\hline
\end{tabular}




\begin{tabular}{|c|c|c|c|c|c|}
\hline http://ocw.mit.edu & Mellon, MIT & & & & \\
\hline $\begin{array}{lr}\text { OCW } & \text { Finder } \\
\text { http://ocwfinder.com }\end{array}$ & OCW Initiative & $\begin{array}{l}\text { All subjects, } \\
\text { postsecondary }\end{array}$ & $\begin{array}{l}10,000+? \\
(2005)\end{array}$ & Courses & $\begin{array}{l}\text { Creative } \\
\text { Commons }\end{array}$ \\
\hline $\begin{array}{l}\text { Open Learn } \\
\text { http://openlearn.ope } \\
\text { n.ac.uk/ }\end{array}$ & Institutional & $\begin{array}{l}\text { All subjects, } \\
\text { postsecondary }\end{array}$ & $\begin{array}{l}500+ \\
\text { units } \\
(2006)\end{array}$ & $\begin{array}{lll}\begin{array}{l}\text { Units for } \\
\text { hours }\end{array} & & \text { of } \\
\text { learning } & & \end{array}$ & $\begin{array}{l}\text { Creative } \\
\text { Commons }\end{array}$ \\
\hline $\begin{array}{l}\text { http://webcast.berkel } \\
\text { ey.edu/ }\end{array}$ & Institutional & $\begin{array}{l}\text { All subjects, } \\
\text { postsecondary }\end{array}$ & $\begin{array}{l}1000 \text { 's } \\
\text { (2002) }\end{array}$ & \begin{tabular}{ll}
\multicolumn{2}{l}{ Video/audio } \\
recordings of \\
courses & $\&$ \\
events &
\end{tabular} & $\begin{array}{l}\text { Creative } \\
\text { Commons } \\
\text { starting } \\
2007\end{array}$ \\
\hline $\begin{array}{l}\text { Wikiversity } \\
\text { http://en.wikiversity. } \\
\text { org/wiki/Wikiversity } \\
\text { :Main_Page }\end{array}$ & $\begin{array}{l}\text { Wikimedia } \\
\text { Foundation }\end{array}$ & $\begin{array}{l}\text { All subjects, all } \\
\text { levels }\end{array}$ & $\begin{array}{l}10,000+ \\
(2006)\end{array}$ & $\begin{array}{l}\text { Various types; } \\
\text { all wiki- } \\
\text { integrated }\end{array}$ & $\begin{array}{l}\text { Creative } \\
\text { Commons }\end{array}$ \\
\hline $\begin{array}{l}\text { World Lecture } \\
\text { Project } \\
\text { http://www.world- } \\
\text { lecture-project.org/ }\end{array}$ & Unknown & $\begin{array}{l}\text { All subjects, } \\
\text { postsecondary }\end{array}$ & $\begin{array}{l}1000+ \\
(2007 ?)\end{array}$ & $\begin{array}{l}\text { Video } \\
\text { recordings of } \\
\text { lectures }\end{array}$ & Various \\
\hline \multicolumn{6}{|c|}{ S P E C I F I C E D U C A T I O N A L D O M A I N S } \\
\hline $\begin{array}{l}\text { Digital Library for } \\
\text { Earth } \quad \text { System } \\
\text { Education (DLESE) } \\
\text { http://dlese.org/librar } \\
\text { y/index.jsp }\end{array}$ & $\begin{array}{l}\text { National Science } \\
\text { Foundation }\end{array}$ & $\begin{array}{l}\text { Earth sciences, } \\
\text { all levels }\end{array}$ & $\begin{array}{l}10,000+ \\
(2001)\end{array}$ & Websites & $\begin{array}{l}\text { All rights } \\
\text { reserved }\end{array}$ \\
\hline $\begin{array}{l}\text { Health Education } \\
\text { Assets Library } \\
\text { http://www.healcentr } \\
\text { al.org/ }\end{array}$ & $\begin{array}{l}\text { National Science } \\
\text { Foundation }\end{array}$ & $\begin{array}{l}\text { Health sciences, } \\
\text { all levels }\end{array}$ & $\begin{array}{l}20,000+ \\
(2003)\end{array}$ & All types & $\begin{array}{l}\text { Creative } \\
\text { Commons }\end{array}$ \\
\hline $\begin{array}{l}\text { Maricopa Learning } \\
\text { Exchange } \\
\text { http://www.mcli.dist } \\
\text {.maricopa.edu/mlx }\end{array}$ & $\begin{array}{l}\text { Maricopa County } \\
\text { colleges } \\
\text { (Phoenix) }\end{array}$ & $\begin{array}{l}\text { Emphasis on IT } \\
\text { and skills }\end{array}$ & $\begin{array}{l}1500+ \\
\text { packages } \\
(2002)\end{array}$ & $\begin{array}{l}\text { Documents } \\
\text { and other } \\
\text { types }\end{array}$ & $\begin{array}{l}\text { Creative } \\
\text { Commons }\end{array}$ \\
\hline
\end{tabular}

There are a number of significant features or trends to be highlighted from this listing. First, the table indicates that many collections, including those established before the emergence of Creative Commons (e.g., Connexions and MERLOT), are now using Creative Commons licensing whereever possible. It is also worth noting that the funding for the operations of many of the projects is either provided by a parent institution (e.g., Rice University, Maricopa County Colleges), by a governmental organization (e.g., DLESE is supported by the National Science Foundation; JISC, which supports Intute, is funded by the UK National Lottery), or by a combination of these types of sources. Only MERLOT, which gains at least some of its support from institutional or consortial membership fees, has been able to approximate a kind of business model envisioned for many learning object projects. 
The estimated start dates for the collections listed in the table are also significant, with dates clustering around 2000 and also around the second half of the current decade. (There are seven repositories with start dates of 1999-2002, five with start dates from 2006-2007, and only two with dates falling between 2003 and 2005.) What this table does not indicate, of course, is the many projects that have fallen inactive or been discontinued. Only by looking at approaches that have met with longer-term success and longevity and also at those that have met with less desirable fates is it possible to understand the nature and the enormity of the sustainability challenge online educational resource collections face.

\section{The Sustainability Challenge}

The collections listed in Table 1 that are seven years old or older can be seen as having addressed the sustainability challenges that this paper argues are of paramount importance. Those projects that have gone online only in the last two or three years, one can surmise, may yet need to overcome sustainability challenges that have resulted in the discontinuation of many similar projects. Unsurprisingly, the question of sustainability and longevity of learning resource collections is one that is structurally excluded from surveys and other forms of research: The failure of a project's sustainability or its business model is by definition not the subject of research for that project; and there is little incentive for research and reporting to focus on the many projects and models that have run aground of sustainability challenges. But knowledge of the success and also of the failure of educational resource projects is indispensable for recent and up-coming projects. Open educational resource projects, in this sense, can learn a great deal from previous learning object initiatives and collection projects, regardless of their ultimate fate.

The timeline presented in Figure 1 indicates the lifespan of a number of repository projects over a 10 -year period. Again, the intention is to be illustrative rather than exhaustive, with most dates being estimated and approximate rather than confirmed and exact. With only a few exceptions, the initiatives included in the timeline diagram are those that deliberately chose the "learning object" label to be associated with their efforts, invoking with it the attendant emphases on technological solutions and content modularity. Those shown on the top of the shaded timeline bar are Canadian collections, and those at the bottom are the result of American, European, or international efforts. 


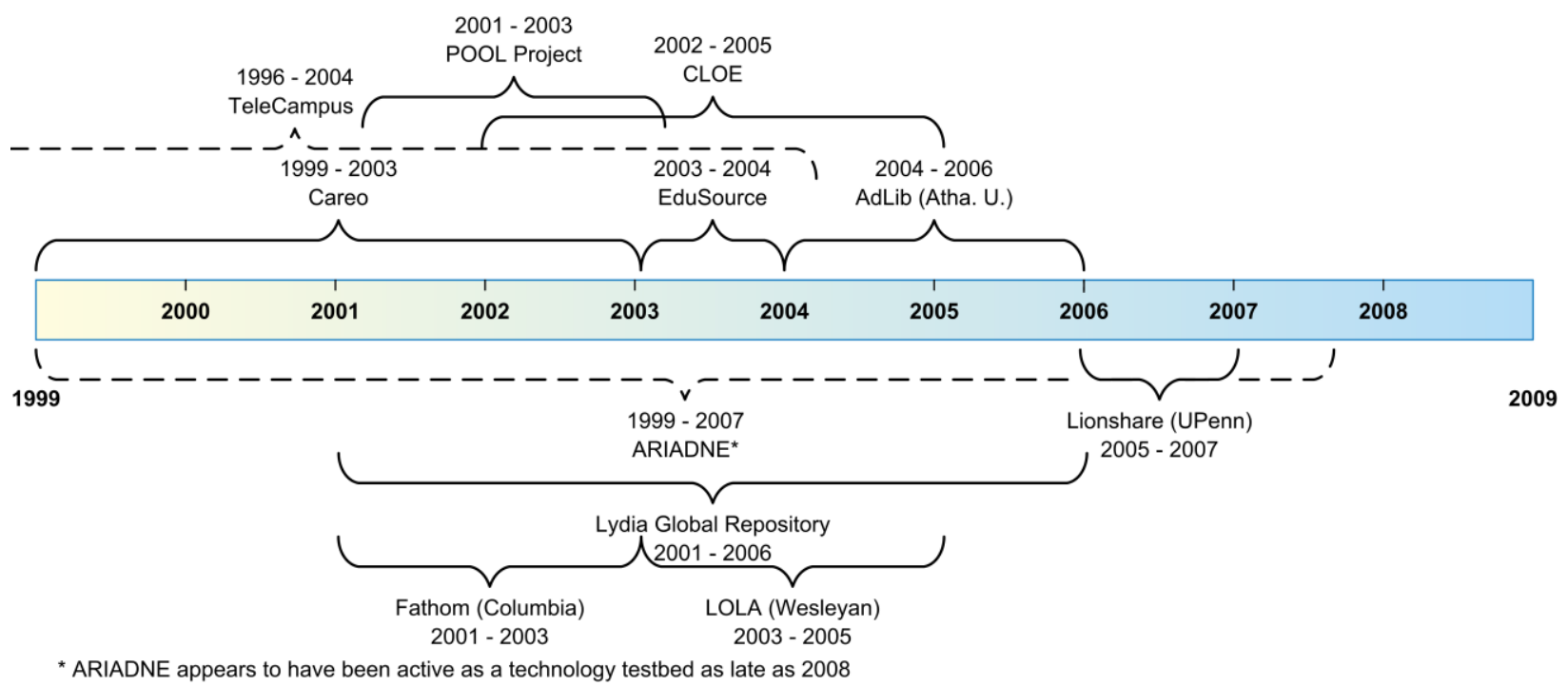

Figure 1. Inactive or discontinued collection projects over the last 10 years.

The projects listed vary in their approaches to both technology and sustainability. For example, the initiatives listed include a number of different technical architectures, with the Careo and Lydia projects using a centralized server, the EduSource and CLOE initiatives taking a distributed approach, and POOL and Lionshare projects focusing on a peer-to-peer model. Different approaches to collection policy sustainability are also illustrated, including a "virtual economy" model adopted in the CLOE project, a collaborative, consortial model developed for Fathom, and a more explicitly commercial model associated with the Lydia Global Repository.

It is important to note that without exception the projects included in this timeline share at least two common characteristics:

- First, even though most projects began after MIT's initiative in open courseware, none prioritized the collection of contents that were in the public domain or that were subject to Creative Commons licensing.

- Second, their collection mandates were not limited to a specific subject area or to a particular community of subject specialists; instead, all of the projects shown included all educational subjects and topics.

- Third, half of the projects shown began between 2001 and 2003.

This last observation goes some way to explaining the relative lack of active projects in Table 1 with start dates in this range and lends some credence to the claim that substantial sustainability challenges come relatively early in a collection's lifetime. As a related observation, it is worth noting that there are only two projects included on this chart whose lifespan exceeds five years: the TeleCampus project, which began before the term learning objects or repositories were in use and received support from a local government source, and ARIADNE, which received funding from the European Union and which in the last few years has served (largely) as a testbed for the 
development of different technologies related to the searching and administration of learning objects. Outside of these two projects, the average lifetime of the repositories included above is less than three years. It is not surprising that this number correlates broadly to the timescales typical for funding research and development projects. Consequently, it is disquieting to read in a recent report on open educational resources that "the majority of OER development" is also "undertaken on a project basis" (D'Antoni, 2008, p. 18). The clear sustainability lesson from both this listing of inactive projects and the earlier listing of active efforts is the importance of ongoing, operational institutional or consortial funding for educational resource collections and the difficulty of realizing alternative funding models. Online educational resource initiatives of this kind, one can conclude, need to be seen as processes or services rather than as products that persist of their own accord.

If this could be labeled as the first lesson of sustainability, the importance of community is the second lesson that can be derived from Table 1 and Figure 1. Only projects that are large-scale, well-funded, and able to benefit from a first-mover advantage (i.e., being one of the first of their kind) seem to have any chance of developing collections whose scope extends to all educational subjects. There are many collections catering to the needs of a single subject specialist community (or a small, interrelated subset of such communities) that provide evidence of sustainability. Three of the active collections with specific subject emphases listed earlier, for example, have outlived the "sustainability crunch" that seems to come in the third year of so many projects. Finally, it is also worth noting that at least two of the larger, subject-inclusive repositories in Table 1 (MERLOT and Intute) represent aggregations of smaller, subject-specific collections that serve clearly-defined subject specialist communities. Speaking of subject specialization and the scope of project collections, one could conclude that groups of subject specialists can provide ready-made communities of practice for repositories, and that the scope of any collection must be matched by its scale.

These general observations are commensurate with a survey report recently released by UNESCO as a follow-up to the Forum on the Impact of Open Courseware mentioned at the outset. Entitled Open Educational Resources: The Way Forward, the document ranked 15 of the top concerns of the "OER international community of interest" (D'Antoni, 2008). The issue of sustainability of OER projects, unsurprisingly, was one of the top concerns $\left(4^{\text {th }}\right.$ out of 15 ). The top three challenges or issues speak clearly to issues implied in the sustainability challenge:

1. awareness raising and promotion;

2. communities and networking of creators and users; and

3. capacity development, specifically as it relates to the development and pedagogical application of OERs.

These concerns share a number of characteristics in common: None are related to technology or to technological solutions (the need for technical tools ranked $12^{\text {th }}$ ). None raise issues such as ease of use or cost-savings - two concerns receiving considerable attention in the literature associated with learning objects (e.g. Weller, 2004). Instead, these top concerns, as the report's author explains, are of a "community focused" and "decentralized" nature (D'Antoni, 2008, p. 
17). They underscore incompatibilities between pedagogical and community cultures, on the one hand, and the practices and priories associated with developing, sharing, and utilizing online instructional content, on the other. This echoes concerns that have been voiced for years by those involved in the promotion of learning objects. One survey of faculty from 2003 shows that a lack of knowledge, a lack of technical ability, and a lack of pedagogical skills were among the top factors impeding "the adoption of learning objects" at one research-intensive university (Griffith, 2003, p.8). Other articles in the learning objects literature underscore "the importance of taking ...context and culture into account when developing and implementing technological solutions in complex social systems" (Casey, Proven, \& Dripps, 2006, p. 2; see also Friesen, 2003). "The current situation," as another article from the same time-period observes, "can be best described as high-level ambitions with poor implementation" (van der Klink \& Jochems, 2004, p. 151; as cited in Casey, Proven, \& Dripps, 2006, p. 3) The problem, however, is that cultures, policy, and procedure are not designed and implemented; they evolve - often with excruciating slowness.

\section{Possibilities for Change}

The situation outlined in surveys of stakeholders and educators, whether of local faculty in 2003 or globally in 2007, reveal a vicious circle of "chicken and egg." The necessary preconditions for viability - awareness, capacity, community, cultural change - are identical with what would be the results of success. However, a closer look at one of the small number of successful, pathbreaking projects listed above points to other possibilities. This is the MIT OpenCourseWare project, which has been responsible for catalyzing broader developments specifically in OCW and OER. A 2005 Program Evaluation Findings Report for the MIT OCW highlights a range of factors associated with the success of this project. Some of these factors and findings have been widely celebrated and others surprisingly ignored.

1. First, a widely recognized finding is the fact that MIT courses and course contents are benefitting users globally. The majority of use takes place outside of the United States itself, with a substantial minority of users coming from outside of OECD-member (or developed) nations (MIT OCW, 2005). The humanitarian, assistive, and ameliorative potential of open courseware, in other words, is clear: the majority of its use is from nations with less developed university infrastructures than the USA.

2. A further important finding is that the majority of the use of MIT courses is for selfdirected, informal learning, namely to "improve" or "enhance personal knowledge" or to "explore areas outside [one's] professional field" (MIT OCW, 2005, pp. 28, 32; MIT OCW, 2009; emphases added). In other words, the majority of the use of this material not only takes place outside of the USA, it also occurs outside in the context of reuse and adaptation by teachers or instructional designers. Together, the first and second factors explain a kind of contradiction apparent in the MIT initiative: it is educationally valuable without detracting from the educational value of the face-to-face activities on which the collected content is based.

3. A correlative finding is that the MIT resources, despite the ambiguity of terms like educational resources or courseware, are actually being used and followed as courses, within the context of the syllabi and other course structures and conventions. 
A fourth and final finding (or rather, set of findings) is connected to the relationship of the project to MIT itself as an institution. This finding provides clear evidence of multiple areas of significant benefit accruing to MIT the institution from the open courseware project, and it provides a positive illustration of important possibilities for change. The report states that "OCW use is centered on subjects for which MIT is recognized leader," with areas in technology and science accounting for $62 \%$ of traffic (MIT OCW, 2005, p. 2). Majorities of students and faculty at MIT, moreover, use the site to support their study and teaching, and $32 \%$ of faculty say that putting materials online has improved their teaching (MIT OCW, 2005, pp. 2-4). Finally, the role of the project in student recruitment is significant: $16 \%$ of the student users employ the MIT courses to "plan a course of study," and "35 percent of freshmen who were aware of OCW prior to deciding to attend MIT indicate the site was a significant or very significant influence on their choice of school" (cited in Wiley, 2006, p. 6). Significantly, this percentage of students more than quadrupled from the year before. Commenting on this rapidly growing awareness of student recruits, David Wiley presents a conclusion that may be of the utmost significance for OER: "The time will come when an OpenCourseWare or similar collection of open access educational materials will be as fully expected from every higher education institution as an informational website is now" (2006, p. 6).

Therein lies one of the most powerful drivers of adoption of OERs and of boader change sought by the advocates of their adoption and use. Simply put, this is enlightened institutional selfinterest. Wiley makes the case in connection with institutional service and recruitment, but MIT has benefited in many other ways from its early and daring investment in open courseware. Although MIT is able to leverage an already existing global reputation and first-mover advantage, many of the benefits it has been able to realize would apply to smaller institutions as well. This includes student recruitment, the potential for improving teaching and for better supporting learning, and a kind of viral marketing of the quality of teaching and learning in areas of strategic institutional interest. Institutions looking at following in MIT's footsteps enjoy the advantage that effective licensing, consortia, and growing awareness are all in place. They need not risk financial and cultural capital on creating yet another collection or repository, but instead can invest it in the quality and accessibility of their course offerings. This is enabled through the Open CourseWare Consortium and its OCW finder, which combines and centralizes offerings from "more than 200 higher education institutions and associated organizations from around the world" to create "a broad and deep body of open educational content using a shared model" (OCW Consortium, 2009). It is worth noting that the OCW Consortium, which appears to have obtained many of its most prestigious members only after 2005 (the publication year of the report cited above), essentially provides other institutions with the means of applying the MIT model to a subset of their courses. It only asks of its members a contribution of 12 courses to its growing collection of over 10,000 courses. This low barrier to entry, as well as the example provided by an expanding number of reputable member institutions, has resulted in the kind of exponential growth shown in the graph below. 


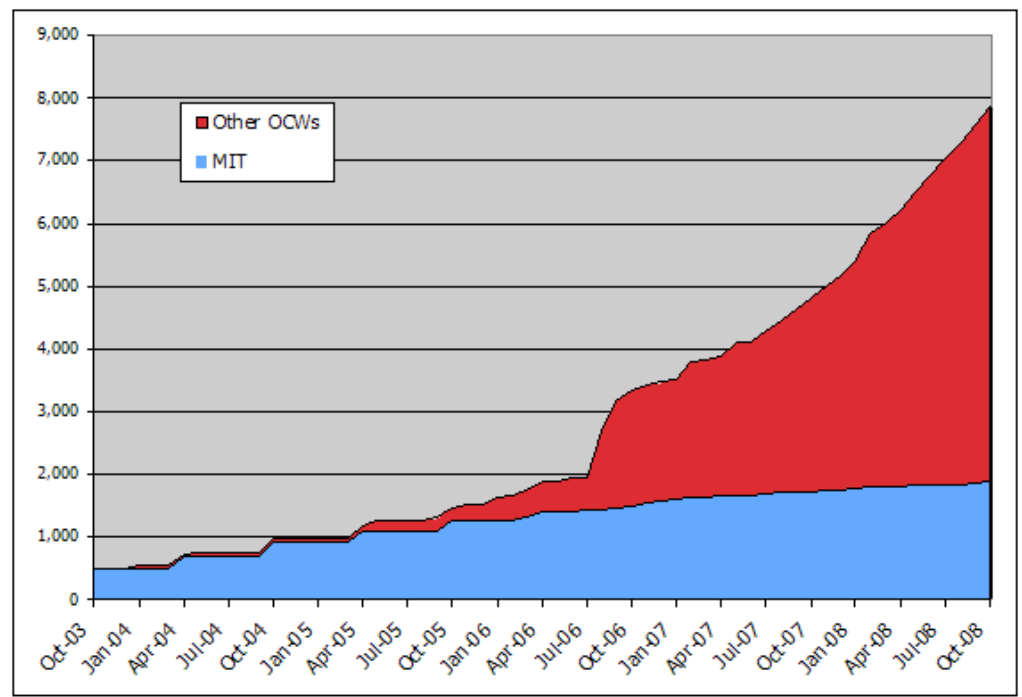

Figure 2. Open courseware production in the Open Courseware Consortium (Caulfield, 2008; used with permission).

The hope is that examples, evidence, and arguments of the kind provided in the MIT report and the graph in Figure 2 - targeted at existing institutional priorities and interests - will lead to action and investment whose effects ultimately extend well beyond present institutional interests. The point, as Wiley explains, is that "this strategy of openness" holds out the promise of "catalyzing further innovations" (2006). And such innovations, above all in practice, community, and policy, have the potential of fomenting the necessarily gradual, cultural sea change sought by the OECD and others to meet their lofty but laudable goals. 


\section{References}

Allan, K. (2008). A primer on e-learning. Retrieved from http://www.futurelab.org.uk/resources/publications-reports-articles/webarticles/Web-Article948.

Carey, T. (2003). About CLOE. Retrieved from http://learnware.uwaterloo.ca/projects/CCCO/cloe_about_find.html.

Casey, J., Proven, J., \& Dripps, D. (2006). Geronimo's cadillac: Lessons for learning object

repositories. Retrieved from http://www.csfic.ecs.soton.ac.uk/Casey.doc.

Chiappe, A., Segovia, Y., \& Rincon, Y. (2007). Toward an instructional design model based on learning objects. Educational Technology Research and Development, 55(6), 671-681.

Caulfield, M. (2008). OCW production in the OCWC, 2003 to present (w/ chart). Retrieved from http://ocwblog.org/2008/11/18/ocw-production-in-the-ocwc-2003-to-present-w-chart/.

D'Antoni, S. (2008). Open educational resources: The way forward deliberations of an international community of interest. Retrieved from http://oerwiki.iiepunesco.org/images/4/46/OER_Way_Forward.pdf.

Downes, S., Babin, G., Belliveau, L., Blanchard, R., Levy, G., Bernard, P., Paquette, G., \& Plourde S., (2004). Distributed digital rights management: The EduSource approach to DRM. Retrieved from http://www.downes.ca/files/DDRM_14April2004.pdf.

Friesen, N. (2004). Three objections to learning objects. In R. McGreal (Ed.), Online education using learning objects (pp. 59-70). London: Routledge. Draft available at http://www.learningspaces.org/n/papers/objections.html.

Geser, G. (2007). Open educational practices and resources: OLCOS roadmap 2012. Salzburg Research EduMedia Group. Retrieved from http://www.olcos.org/cms/upload/docs/olcos_roadmap.pdf.

Holzinger, A., \& Ebner, M. (2003). Interaction and usability of simulations \& animations: A case study of the Flash technology. Proceedings of IFIP INTERACT03: Human-Computer Interaction (p. 777). Zurich, Switzerland.

Johnson, L.F. (2003). Elusive vision: Challenges impeding the learning object economy. Retrieved from http://download.macromedia.com/pub/solutions/downloads/elearning/elusive_visi on.pdf. 
MIT OCW (2005). MIT OpenCourseWare 2005 program evaluation findings. Retrieved from http://ocw.mit.edu/ans7870/global/05_Prog_Eval_Report_Final.pdf.

MIT OCW (2009). Site statistics. Retrieved from http://ocw.mit.edu/OcwWeb/web/about/stats/.

OCW Consortium. (2009). OCW Consortium: About us. Retrieved from http://www.ocwconsortium.org/about-us/about-us.html.

Griffith, R. (2003). Learning objects in higher education. Retrieved from http://www.academiccolab.org/resources/webct_learningobjects.pdf.

UNESCO (2002). Forum on the impact of Open Courseware for higher education in developing $\begin{array}{llll}\text { countries final report } & \text { Retrieved }\end{array}$ http://unesdoc.unesco.org/images/0012/001285/128515e.pdf.

UNESCO (2009). About World Heritage. Retrieved from http://whc.unesco.org/en/about/.

Van der Klink, M., \& Jochems, W. (2004). Management and organization of integrated elearning. In W. van Merriënboer \& R. Koper (Eds.), Integrated e-learning: Implications for pedagogy, technology and organization (pp. 151-163). London: Routledge \& Falmer.

Weller, M. (2004). Learning objects and the e-learning cost dilemma. Open Learning, 19(3), 293-302.

Wiley, D. A. (2000). Connecting learning objects to instructional design theory: A definition, a metaphor, and a taxonomy. In D. A. Wiley (Ed.), The instructional use of learning objects: Online version. Retrieved from http://reusability.org/read/chapters/wiley.doc.

Wiley, D. A. (2006). Testimony to the Secretary of Education's Commission on the Future of Higher Education. Retrieved from http://www.ed.gov/about/bdscomm/list/hiedfuture/3rd-meeting/wiley.pdf.

Yuan, L., MacNeill, S., \& Kraan, W. (2008). Open educational resources-Opportunities and challenges for higher education. Retrieved from http://learn.creativecommons.org/wpcontent/uploads/2008/09/oer_briefing_paper. pdf.

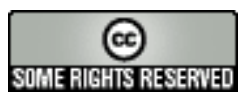

